V.S. Malyar, A.V. Malyar, A.S. Andreishyn

\title{
A METHOD FOR CALCULATING MECHANICAL CHARACTERISTICS OF INDUCTION MOTORS WITH SQUIRREL-CAGE ROTOR
}

Purpose. Development of a method for calculating mechanical characteristics of induction motors, taking into consideration saturation of the magnetic path and displacement of the current in the rotor bars. Methodology. The algorithm is based on calculating the steady-state mode of induction motor operation for a set slip, described by a system of non-linear algebraic equations of electrical equilibrium, whereas the mechanical characteristic is evaluated as a set of steady-state modes using parameter continuation method. The idea of the steady-state mode calculation consists in determining vectors of currents and flux linkages of the motor circuits, using which makes it possible to evaluate the electromagnetic torque, active and reactive powers, etc. Results. The study resulted in the development of a method and algorithm for calculating static characteristics of induction motors, which allows looking into the effect of different laws of voltage regulation on the mechanical characteristics, depending on the frequency change. Originality. An algorithm for calculating mechanical characteristics of the squirrel-cage induction motor was developed based on the mathematical model of the induction motor in which electromagnetic parameters are calculated using real saturation curves for the main magnetic flux and leakage fluxes, and displacement of the current in the rotor bars is evaluated by presenting the rotor winding as a multi-layer structure. Applying the transformation of the electrical equilibrium equations into the orthogonal axes enabled a significant reduction of calculation volume without impairing the accuracy of the results. Practical value. The developed algorithm allows studying the effect of different laws of scalar regulation of the voltage on the mechanical characteristics of the induction motor in order to obtain the necessary torque-speed curves for their optimization. It can be used for programming frequency converters. References 10, figures 3.

Key words: induction motor, squirrel-cage rotor, static characteristics, saturation, displacement of the current.

Запропоновано алгоритм розрахунку механічних характеристик асинхронних двигунів 3 короткозамкненим ротором при різних частотах напруги живлення. В основу розрахунку покладено математичну модель асинхронного двигуна, в якій враховується насичення магнітопроводу $i$ витіснення струму в стержнях короткозамкненого ротора. Електромагнітні процеси у двигуні описуються системою нелінійних рівнянь електричної рівноваги, записаної в перетворених до ортогональних осей координат, яка розв'язується ітераційним методом Ньютона разом з методом продовження по параметру. Для обчислення потокозчеплень контурів та диференціальних індуктивностей використовуються характеристики намагнічування основним магнітним потоком, а також потоками розсіювання статора і ротора. Для урахування витіснення струму в стержнях ротора короткозамкнена обмотка подається у вигляді багатошарової структури, утвореної розбиттям стержснів по висоті на кілька шарів. Бібл. 10, рис. 3.

Ключові слова: асинхронний двигун, короткозамкнена обмотка, статичні характеристики, насичення, витіснення струму.

Предложен алгоритм расчета механических характеристик асинхронных двигателей с короткозамкнутым ротором при разных частотах напряжения питания. В основу расчета положена математическая модель асинхронного двигателя, в которой учитывается, насыщение магнитопровода и вытеснение тока в стержнях короткозамкнутого ротора. Электромагнитные процессы в двигателе описываются системой нелинейных уравнений электрического равновесия, составленной в преобразованных к ортогональным осям координат, которая решается итерационным методом Ньютона вместе с методом продолжения по параметру. Для вычисления потокосцеплений контуров и дифференциальных индуктивностей используются характеристики намагничивания основным магнитным потоком, а также потоками рассеяния статора и ротора. Для учета вытеснения тока в стерэнях ротора короткозамкнутая обмотка представляется в виде многослойной структуры, образованной разбитием стержней по высоте на несколько слоев. Библ. 10, рис. 3 .

Ключевые слова: асинхронный двигатель, короткозамкнутая обмотка, статические характеристики, насыщение, вытеснение тока.

Introduction. In modern asynchronous electric drives, frequency converters are used to control the speed of rotor rotation. This method of regulation provides high technical and economic performance, since the frequency controlled electric drive opens up wide opportunities for the use of induction motors (IM) in qualitatively new technological processes and provides high energy efficiency. The development of reliable and high-quality microprocessor systems makes it possible to precisely control the operation of the electric drive in accordance with the requirements of a specific technological process, which not only ensures its quality, but also the economy of the electric power. The theoretical and practical aspects of frequency control are described in many fundamental publications [1-4], and features and analysis of scalar and vector control are presented in review papers $[5,6]$. However, the problem of developing methods for studying the mechanical characteristics of IM with different laws of changing the supply voltage, despite the large number of publications, remains unresolved at the proper level.

As it is known, changing the frequency of supply voltage of the IM can smoothly adjust the angular speed of rotation of the stator magnetic field, and the slip of the rotor thus does not change. For electric drives with a small range of regulation and comparatively low dynamic properties, so-called scalar control is used [1,4], which is relatively simple in realization. In contrast to the vector one, it is based on the use of modules of quantities that (C) V.S. Malyar, A.V. Malyar, A.S. Andreishyn 
determine the electromagnetic torque. Since the electromagnetic processes depend on the internal parameters of the IM, the inaccuracy of their determination leads to an inaccuracy in the determination of the electromagnetic torque and, as a consequence, significant deviations of the speed of rotation of the rotor from the given value [1]. This is due to the fact that in the existing control algorithms for frequency-regulated asynchronous electric drives, mathematical models of IM are used based on substitution circuits or linear differential equations [1-4], and the mechanical characteristics are calculated according to the Kloss formula, which is approximate. Changing the parameters of the squirrel-cage rotor, in particular the active resistance, is not taken into account or taken into account by the corresponding coefficients. The use of classical substitution circuits does not allow adequately to take into account all the factors influencing the processes in the motor when changing the frequency, and does not guarantee the reliability of the calculation results, especially for deep-slotted IMs. The problems of the adequacy of the results of mathematical modeling are not solved by substitution circuits with variable frequency dependent parameters, because as a result of the saturation of the magnetic core, flux linkage of the IM circuits and, therefore, electromagnetic parameters are nonlinearly dependent on all its currents and their frequency.

In order to control the operation of the IM, which operates in the frequency controlled electric drive system, it is necessary to know the values of its internal parameters, in particular the active and reactive stator and rotor resistance of the stator and rotor that are continuously changing. Undeniably, the most accurately they can be determined on the basis of solving the problem in field formulation [7, 8], however, such software requires a considerable amount of memory and time to calculate, and therefore can not meet the requirements for the speed of response of the frequency converter to the flow the process. The intermediate position is occupied by circuit methods for calculating electromagnetic parameters and active resistance. Therefore, the actual problem is the development of a mathematical model that allows one to calculate the mechanical characteristics taking into account the change in parameters due to the saturation of the magnetic core and the displacement of the current in the rods of the squirrel-cage winding as having a determining influence on the characteristics of the IM. In addition, for efficient frequency control of electric drive an important and determining factor is the speed and bulkiness of software for calculating the frequency characteristics of asynchronous electric drives, which are the basis of control algorithms.

The goal of the work is the development of a numerical method for calculating mechanical characteristics under different laws of changing the supply voltage of the IM and its frequency using a mathematical model based on the equation of the electromagnetic equilibrium of the motor circuits, which make it possible to take into account the saturation of the magnetic core and the displacement of the current in the rods of the squirrel-cage rotor.

Mathematical model. The object of the study is a IM with a squirrel-cage winding of a rotor, which is powered by a three-phase network with a symmetric voltage system. For the analysis of electromagnetic processes in the IM, a mathematical model is used built using orthogonal coordinate axes, which enables the analysis of processes by computer simulation, taking into account both saturation and displacement of current in the rods of a squirrel-cage winding of the rotor with a minimum amount of computations. To take into account the saturation, the magnetization characteristics of magnetization both by the main magnetic flux and the scattering fluxes are used, and to take account the displacement of the current, the rods together with the squirrel-cage rings are separated by height into $n$ layers, resulting in $n$ windings on the rotor that are covered by different magnetic scattering fluxes. The idea of such an approach is presented in [9]. As shown in [10], in practice $n \leq 5$. The three-phase winding of the stator and a multiphase winding of the rotor are reduced to two-phase windings according to the generally accepted method.

Electromagnetic processes in the dynamic modes of the IM are described by a system of differential equations, which is reduced to algebraic systems in the system of orthogonal axes $x, y$ under constant rotational speed. If the representational vector of the power supply voltage with the $x$-axis, are combined, which is commonly practiced, this system has the form

$$
\begin{gathered}
\omega_{0} \psi_{s y}-r_{r} i_{s x}+U_{m}=0 \\
-\omega_{0} \psi_{s x}-r_{s} i_{s y}=0 \\
s \omega_{0} \psi_{r 1 y}-r_{1} i_{r 1 x}=0 \\
-s \omega_{0} \psi_{r 1 x}-r_{1} i_{r 1 y}=0 \\
\cdots \\
s \omega_{0} \psi_{r n y}-r_{n} i_{r n x}=0 \\
-s \omega_{0} \psi_{r n x}-r_{n} i_{r n y}=0
\end{gathered}
$$

where $U_{m}$ is the amplitude value of the phase voltage; $\psi_{s x}$, $\psi_{s y}, \psi_{r 1 x}, \psi_{r 1 y}, \ldots, \psi_{r n x}, \psi_{r n y}$ are the flux linkages and currents $i_{s x}, i_{s y}, i_{r 1 x}, i_{r 1 y}, \ldots, i_{r n x}, i_{r n y}$ of the transformed stator and rotor circuits, respectively; $r_{s}, r_{r 1}, \ldots, r_{r n}$ are the active resistances of these circuits; $\omega$ is the angular frequency of the power supply voltage; $s$ is the rotor slip.

The flux linkages of the circuits are determined on the basis of the use of the magnetization curves by the main magnetic flux $\psi_{\mu}$ and the scattering fluxes of the stator $\psi_{\sigma s}$ windings and the rotor $\psi_{\sigma r}$ windings

$$
\psi_{\mu}=\psi_{\mu}\left(i_{\mu}\right), \quad \psi_{\sigma s}=\psi_{\sigma s}\left(i_{s}\right), \quad \psi_{\sigma r}=\psi_{\sigma r}\left(i_{r}\right) .
$$

where $i_{\mu}, i_{s}, i_{r}$ are the modules of the representational vectors of the corresponding currents: magnetization, stator and rotor

$$
\begin{aligned}
& i_{\mu}=\sqrt{\left(i_{s x}+i_{r x}\right)^{2}+\left(i_{s y}+i_{r y}\right)^{2}} ; \\
& i_{s}=\sqrt{i_{s x}^{2}+i_{s y}^{2}} ; \quad i_{r}=\sqrt{i_{r x}^{2}+i_{r y}^{2}} .
\end{aligned}
$$

Since the rod is divided by height into $n$ elements, the rotor currents are determined as the sum of currents in them 


$$
i_{r x}=\sum_{j=1}^{n} i_{r j x} ; \quad i_{r y}=\sum_{j=1}^{n} i_{r j y} .
$$

The electromagnetic torque of the IM, in the coordinate axes $x, y$, is determined by the formula

$$
M_{e}=1.5 p_{0}\left(\psi_{s x} i_{s y}-\psi_{s y} i_{s x}\right),
$$

where $p_{0}$ is the number of pairs of poles.

Active and reactive powers are determined by the formulas

$$
P=1.5\left(u_{s x} i_{s x}-u_{s y} i_{s y}\right) ; \quad Q=1.5\left(u_{s y} i_{s x}-u_{s x} i_{s y}\right) .
$$

Algorithm for calculation of characteristics. The basis of the algorithm is the calculation of the steady state mode of operation of the IM for a given slip $s$, which is described by the system of algebraic equations (1), and the static characteristic is calculated as a set of steady state modes. The essence of the calculation of the steady state mode is to determine the vectors of currents and the flux densities of the circuit of the motor using which we can determine the electromagnetic torque, the active and reactive powers, and so on.

Having the given values of the power supply voltage of the stator winding and slip, the calculation of the steady state mode reduces to the solution of the system of algebraic equations (1). Due to the saturation of the magnetic core, the electromagnetic connections between its electrical circuits are nonlinear, hence the flux linkage of each circuit is nonlinearly dependent on the vector of currents

$$
\vec{i}=\operatorname{colon}\left(i_{s x}, i_{s y}, i_{r 1 x}, i_{r 1 y}, \ldots, i_{r n x}, i_{r n y}\right),
$$

which depend on the value of the supply voltage and are determined by the electromagnetic parameters of the IM.

One of the most effective methods for solving nonlinear systems of algebraic equations is Newton iteration method, according to which at each $k$-th step of the iteration the vector $\vec{i}$ is specified by formulas

$$
\vec{i}^{(k+1)}=\vec{i}^{(k)}-\Delta \vec{i}^{(k)} ; A \Delta \vec{i}^{(k)}=\vec{Q}^{(k)},
$$

where $\vec{Q}^{(k)}$ is the vector of the discrepancies of the system (1) at $\vec{i}=\vec{i}^{(k)} ; A$ is the Jacobi matrix, elements of which are differential inductances $L_{j, k}$ of circuits (own at $j=k$ and mutual at $j \neq k$ ) and their active resistances.

To ensure the convergence of the iterative process, it is necessary to obtain an initial approximation of the unknown vector, which is in the zone of attraction of the method. This problem is solved by a differential method, the essence of which in relation to the problem to be solved is as follows.

We introduce into the system (1) a scalar parameter $\varepsilon$ by multiplying it by the voltage $u_{s x}=\varepsilon U_{m}$. As a result of the differentiation of the resulting nonlinear system by $\varepsilon$ we obtain the differential equation in the form

$$
A \frac{d \vec{i}}{d \varepsilon}=\vec{u},
$$

where $\vec{u}=\operatorname{colon}\left(U_{m}, 0, \ldots, 0\right)$.

Integration with the parameter $\varepsilon$ in the range from $\varepsilon=0$ to $\varepsilon=1$ is equivalent to increasing the applied voltage from zero to the set value. Initial conditions (values of the vector $\vec{i}$ ) are zero, since for $\varepsilon=0$ the vector of the applied voltages is zero. At each step of integration, the vector $\vec{i}$ is clarified by Newton method. Gradual increase of the applied voltage makes it possible at each step to ensure the convergence of the iterative process, and therefore, after several steps of integration with the Euler method, obtain the value of the current vector $\vec{i}$ at a given value of the amplitudes of phase voltages $U_{m}$.

The obtained values are the initial conditions for the calculation of characteristics as coordinates dependencies on the slip.

Thus, the algorithm for calculating the starting static characteristic consists of two stages: the first one calculates the steady-state operation of the IM at the given values of slip and the voltage of the stator winding, and the second one is the calculation of the multidimensional static characteristic as the dependencies $\vec{i}=\vec{i}(s)$ of the coordinates of the vector of circuit currents from slip. In this case, the voltage and frequency are accepted unchanged, and the slip changes in the specified limits. In particular, to calculate the static mechanical characteristic of the IM at a given frequency of supply voltage, we need to set the slip value $s=1$ and according to the above algorithm to determine the value of the coordinates of the mode at a given value of the amplitude of the supply voltage, and then, gradually reducing the value of slip with step $\Delta s$ to zero, by iterative method to calculate the multidimensional dependence $\vec{i}=\vec{i}(s)$, and hence $\vec{\psi}=\vec{\psi}(s)$ as well as the electromagnetic torque $M=M(s)$.

On each step of integration, as well as iterative refinement of the vector $\vec{i}$ by the Newton method, it is necessary to determine the differential inductances of the circuits as nonlinear functions of the vector $\vec{i}$ of the currents.

Results of investigations. An example of the results of the calculation of the characteristics of two types of IM of the same power, which differ in the number of pairs of poles, one of which has a normal execution (4A160S4Y3, $\left.P=15 \mathrm{~kW}, U=220 \mathrm{~V}, I=29.2 \mathrm{~A}, p_{0}=3\right)$ and the second one has an increased starting torque (4AP160S4Y3, $\left.P=15 \mathrm{~kW}, U=220 \mathrm{~V}, I=29.9 \mathrm{~A}, p_{0}=2\right)$ due to the double cage of the rotor is shown in Fig. 1.

Fig. 2 shows the mechanical characteristics of the motors calculated at different supply voltage frequencies under voltage regulation according to the law $U_{m} / f=$ const.

Analysis of the results of calculations (Fig. 1,2) shows that the general view of the characteristics of the electromagnetic torque for IM with a different shape of the slots of the squirrel-cage winding of the rotor is significantly different, and the voltage reduction is proportional to the decrease in frequency does not ensure the immutability of the reloading capacity of the IM.

Shown in Fig. 2 characteristics of the electromagnetic torque correspond to the characteristics of the active power (Fig. 3). 

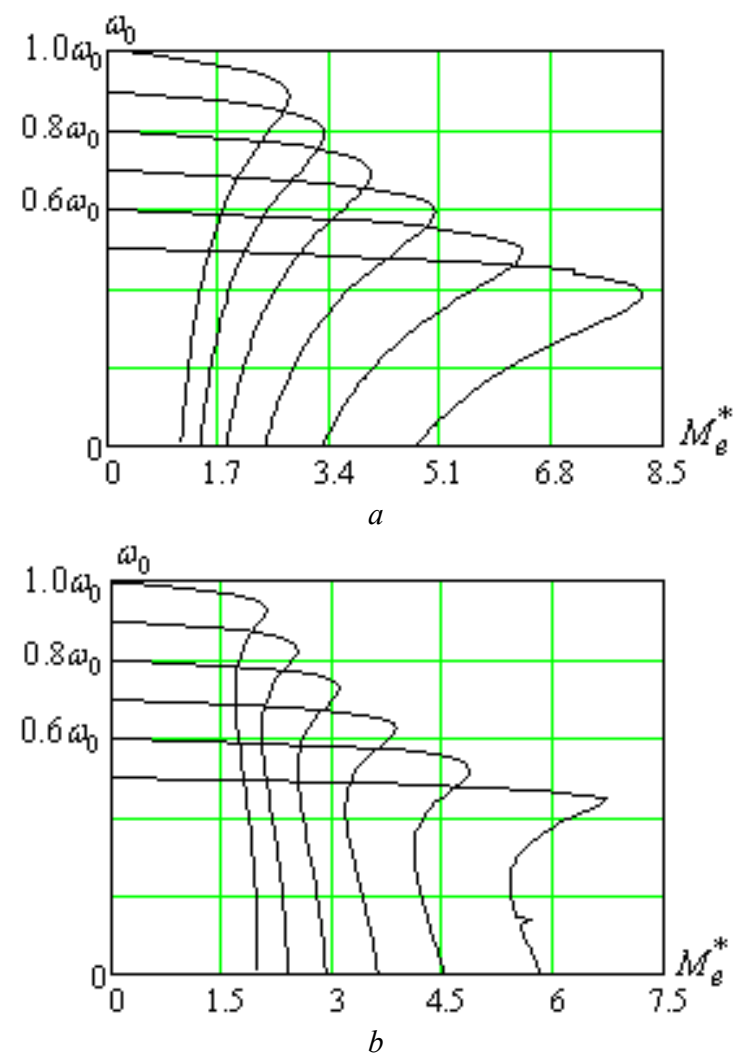

Fig. 1. Mechanical characteristics of motors 4A160S4Y3 (a) and 4AP160S4Y3 (b) calculated with constant amplitude of the supply voltage and its various frequencies $f$
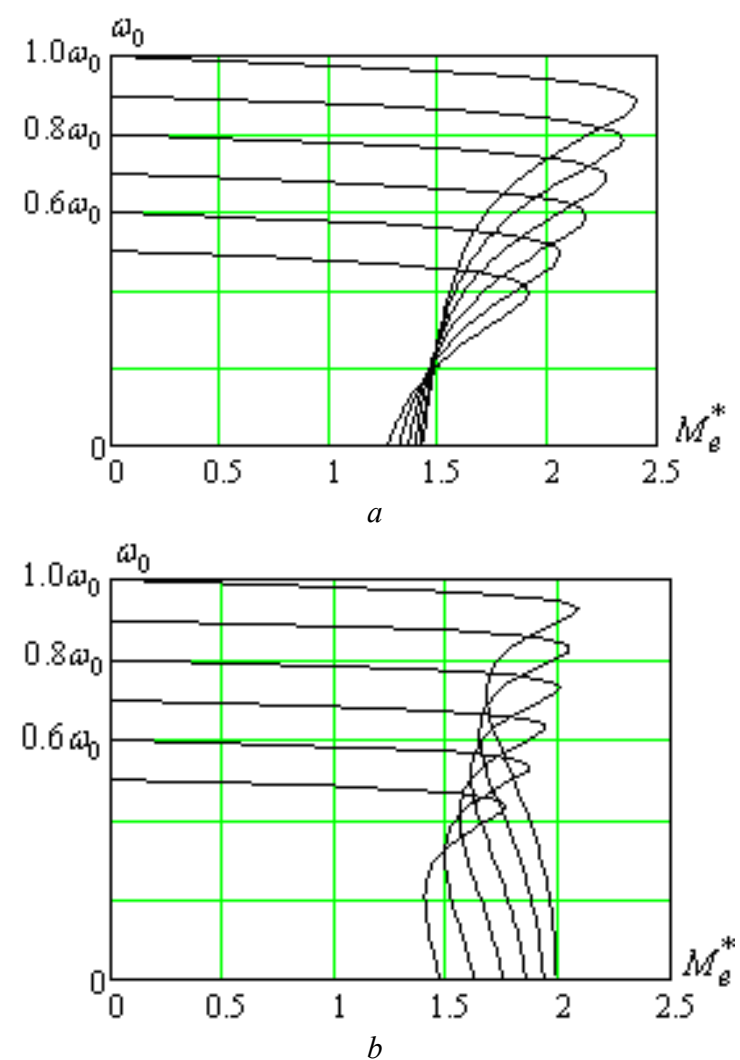

Fig. 2. Mechanical characteristics of motors 4A160S4Y3 $(a)$ and 4AP160S4Y3 (b) calculated at different power supply voltage frequencies supply provided voltage regulation by law

$$
U_{m} / f=\text { const }
$$
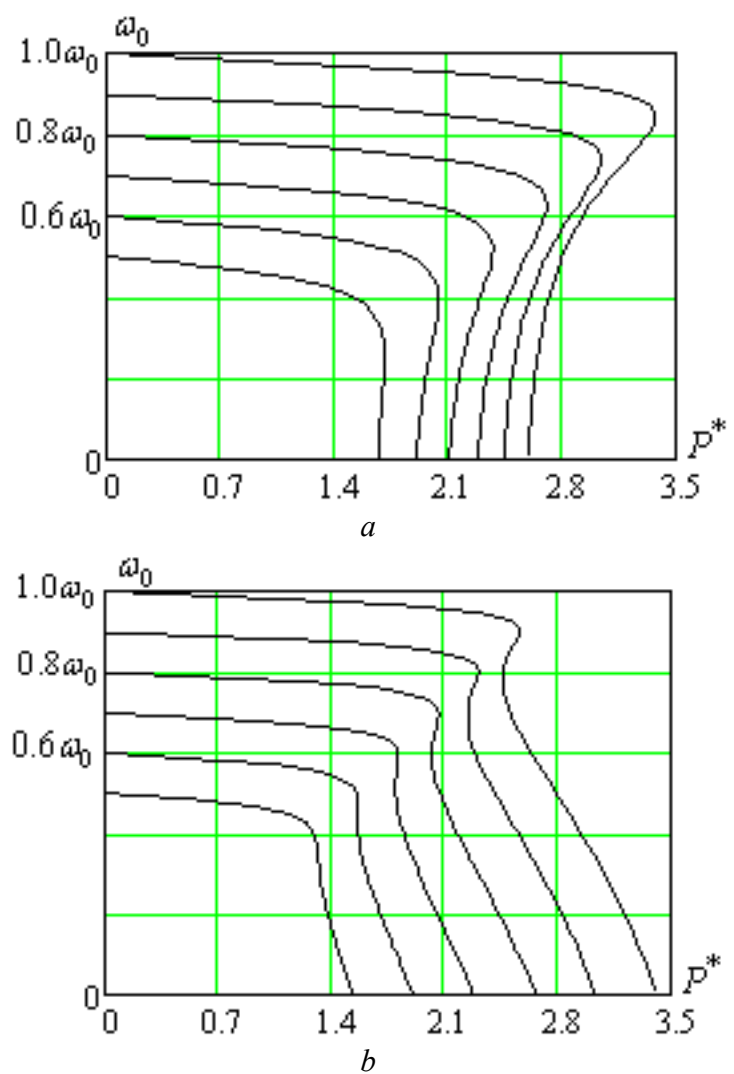

Fig. 3. Characteristics of the active power correspond to the mechanical characteristics shown in Fig. 2, $a, b$

\section{Conclusions.}

1. The proposed method of calculation enables by mathematical modeling methods to analyze the mechanical characteristics of induction motors with squirrel-cage rotor, taking into account saturation and displacement of currents in the rotor rods under different laws of voltage and frequency control in order to provide the necessary law for the change of electromagnetic torque.

2. The developed algorithm of calculation is based on the mathematical model of the IM, in which the real, calculated on the basis of the geometry of the IM magnetic core magnetization characteristic and the dividing along the depth of the slots of the rods of the squirrel-cage winding into elementary ones, which allows to adequately take into account saturation and displacement of current, which is provided the accuracy of the calculation results.

3. The developed mathematical model and the calculation algorithm created on its basis can be used for designing frequency regulated electric drives in order to form the necessary characteristics.

\section{REFERENCES}

1. Pivnyak G.G., Volkov A.V. Sovremennye chastotnoreguliruemye asinkhronnye elektroprivody s shirotno-impul'snoi moduliatsiei [Modern frequency controlled asynchronous electric drives with pulse width modulation]. Dnepropetrovsk, NGU Publ., 2006. 470 p. (Rus).

2. Novotny D.W., Lipo T.A. Vector Control and Dynamics of AC Drives. Clarendon Press Oxford, 2003. 440 p.

3. Pabitra Kumar Behera, Manoj Kumar Behera, Amit Kumar Sahoo. Speed Control of Induction Motor using Scalar Control 
Technique. International Journal of Computer Applications. Proceedings on International Conference on Emergent Trends in Computing and Communication ETCC, 2014, no.1, pp. 37-39. 4. Aspalli M.S., Asha R., Hunagund P.V. Three phase induction motor drive using IGBTs and constant $\mathrm{V} / \mathrm{F}$ method. International Journal of Advanced Research in Electrical, Electronics and Instrumentation Engineering, 2012, vol.1, iss.5, pp. 463-469.

5. Finch J.W., Giaouris D. Controlled AC Electrical Drives. IEEE Transactions on Industrial Electronics, 2008, vol.55, no.2, pp. 481-491. doi: 10.1109/TIE.2007.911209.

6. Boldea I. Control issues in adjustable speed drives. IEEE Industrial Electronics Magazine, 2008, vol.2, no.3, pp. 32-50. doi: 10.1109/MIE.2008.928605.

7. Vaskovskyi Yu.N., Gaydenko Yu.A., Tsivinskiy S.S. Integral characterization of electrical machines with electromagnetic field theory methods. Electrical Engineering \& Electromechanics, 2006, no.1, pp.28-32. doi: 10.2098/2074272X.2016.01.05.

8. Milykh V.I., Polyakova N.V. Determination of electromagnetic parameters of electric machines based on numerical calculations of magnetic field. Electrical Engineering
\& Electromechanics, 2006, no.2, pp.40-46. doi: 10.2098/2074272X.2016.02.09.

9. Rogers G.J., Benaragama D.S. An induction motor model with deep-bar effect and leakage inductance saturation. Archiv für Elektrotechnik, 1978, vol.60, no.4, pp. 193-201. doi: $\mathbf{1 0 . 1 0 0 7 / b f 0 1 5 9 5 1 6 0 . ~}$

10. Stakhiv P., Malyar A. Influence of saturation and skin effect on current harmonic spectrum of asynchronous motor powered by thyristor voltage regulator. Proceedings of the $I V^{\text {th }}$ International Workshop Computational Problems of Electrical Engineering. Gdynia, Poland, June 1-3, 2005. pp. 58-60.

Received 08.11.2018

V.S. Malyar ${ }^{1}$, Doctor of Technical Science, Professor,

A.V. Malyar ${ }^{1}$, Doctor of Technical Science, Professor,

A.S. Andreishyn ${ }^{1}$, Postgraduate Student,

${ }^{1}$ Lviv Polytechnic National University,

12, S. Bandera Str., Lviv, 79013, Ukraine,

phone +380322582119 ,

e-mail: andrii.v.maliar@lpnu.ua

How to cite this article:

Malyar V.S., Malyar A.V., Andreishyn A.S. A method for calculating mechanical characteristics of induction motors with squirrel-cage rotor. Electrical engineering \& electromechanics, 2019, no.2, pp. 9-13. doi: 10.20998/2074272X.2019.2.02. 